\title{
PERANAN JOB ORDER COSTING METHOD DALAM MENENTUKAN HARGA POKOK PRODUKSI (STUDI KASUS PADA CV. TRINITY MANADO)
}

\author{
Jessica Graziella Whitney Runtu \\ Agus Poputra \\ Victorina Tirayoh \\ Fakultas Ekonomi dan Bisnis, Jurusan Akuntansi
Universitas Sam Ratulangi Manado
email : jessicaruntu8194@gmail.com
}

\begin{abstract}
Job order costing is a system that collects product costing and charge to a specific job. Job order costing system is used for companies that produce a veriety of products during certain periods and costs are calculated individually for each job. This study aimed to analyze use job order costing method in determining the production cost on a CV. Trinity Manado. Methods of data analysis used this research is descriptive qualitative research method, where the study was conducted by collecting data and analyze the collected data and provide information. Authors collected data using techniques of documentation and interviews. Based on the research, imposition the factory overhead costs that do CV. Trinity is not quite right. CV. Trinity only imposes an element of overhead costs such as the costs of helper only while electricity costs are not included in the factory overhead cost.
\end{abstract}

Key Word: job order costing, the production cost, factory overhead cost

\section{Latar Belakang}

\section{PENDAHULUAN}

Dunia usaha dewasa ini ditandai dengan semakin ketatnya persaingan diantara perusahaanperusahaan yang ada. Pencapaian laba dapat dilakukan oleh perusahaan dengan berbagai cara antara lain penentuan harga jual, efisiensi biaya produksi dan berbagai cara lain yang berhubungan dengan pencapaian laba. Harga jual suatu produk merupakan salah satu faktor penting disamping faktorfaktor lain yang harus diperhatikan. Seorang pelanggan atau konsumen seringkali memperhatikan harga dalam membuat keputusan apakah ia akan membeli suatu produk atau tidak. Walaupun tidak jarang kualitas lebih diunggulkan daripada harga, namun tidak dapat dipungkiri bahwa harga sangat berperan dalam proses pembuatan keputusan pembelian barang konsumen.

Penetapan harga pokok harus memegang peranan penting pada suatu perusahaan, sebab dari harga pokok dapat dibuat analisa rencana dan kekuatan pemasaran dan penentuan harga jual. Dalam menghitung harus diperhitungkan unsur-unsur apa saja yang dibebankan kedalam biaya produksi. Perhitungan harga pokok produksi membutuhkan informasi biaya. Biaya tersebut dihasilkan lewat akuntansi biaya. Menurut Salman (2013 : 9), akuntansi biaya memegang peranan yang penting kepada pihak manajemen dalam merencanakan dan mengawasi kegiatan, meningkatkan mutu produk dan efisiensi, serta dalam pengambilan keputusan baik strategis maupun keputusan rutin.

Dalam menentukan perhitungan harga pokok produksi ada 2 metode yang dapat digunakan, yaitu process costing dan job order costing. Process costing adalah penentuan harga pokok yang digunakan dalam situasi dimana produksi hanya melibatkan satu produk tunggal saja dan dibuat dalam satu jangka yang lama sekaligus. Contoh industri yang menggunakan metode process costing ini adalah perusahaan manufaktur semen, tepung, bensin, dan perusahaan yang menghasilkan bahan baku lainnya. Sedangkan job order costing suatu metode pengumpulan biaya produksi untuk menentukan harga pokok produksi pada perusahaan atas dasar pesanan. Tujuan metode job order costing untuk menentukan harga pokok pesanan secara keseluruhan dari tiap-tiap pesanan maupun untuk persatuan

Untuk perusahaan yang menggunakan job order costing, perhitungan harga pokok produksi yang tepat menjadi sangat penting karena ketika perusahaan menerima pesanan dari konsumen, maka harus menentukan harga jualnya sebelum pesanan dikerjakan. Harga pokok produksi harus ditentukan secara akurat agar perusahaan tidak mengalami kerugian. Perusahaan harus dapat melakukan akumulasi biaya produksi baik biaya bahan baku, biaya tenaga kerja langsung, maupun biaya 
overhead pabrik (BOP). Biaya produksi yang diakumulasikan tersebut kemudian harus dapat dibebankan untuk tiap pesanan produksi.

$\mathrm{CV}$. trinity merupakan perusahaan yang menggunakan metode job order costing didalam produksinya. Oleh karena itu, CV. Trinity harus melakukan pengakumulasian dan perhitungan elemen biaya produksi baik bahan baku, biaya tenaga kerja langsung, maupun pembebanan biaya overhead parbrik dalam setiap pesanan yang dikerjakan secara akurat. Hal ini bertujuan agar harga jual yang ditetapkan mampu menutup biaya produksi dan menghasilkan laba yang diinginkan.

\section{Tujuan Penelitian}

Tujuan dari penelitian ini adalah untuk menganalisis penerapan metode job order costing dalam menentukan harga pokok produksi pada CV. Trinity Manado.

\section{Konsep Akuntansi}

\section{TINJAUAN PUSTAKA}

Akuntansi adalah aktivitas jasa. Fungsinya adalah untuk menyediakan informasi kuantitatif, terutama yang bersifat keuangan, tentang entitas (kesatuan) usaha yang dipandang akan bermanfaat dalam pengambilan keputusan ekonomi (New York: American Institute of Certified Public Accountants, 1970) dikutip oleh Smith dan Skousen (1987: 3).

Menurut Ahmad dan Abdullah (2012 : 17), akuntansi merupakan suatu kegiatan jasa yang berfungsi menyediakan informasi kuantitatif terutama yang bersifat keuangan mengenai kesatuankesatuan ekonomi tertentu kepada pihak-pihak yang berkepentingan, untuk digunakan sebagai bahan pertimbangan dalam pengambilan keputusan-keputusan ekonomi. Keuangan manajemen dan akuntansi pemerintah sering disebut sebagai "bahasa bisnis", atau lebih tepat disebut bahasa pengambilan keputusan. Semakin dalam menguasai bahasa ini akan semakin baik pula untuk menangani berbagai aspek keuangan dalam kehidupan.

Dari pengertian di atas, dapat disimpulkan bahwa akuntansi adalah sebagai alat ukur yang memberikan informasi umumnya dalam ukuran uang mengenai suatu badan ekonomi yang berguna bagi pihak-pihak intern maupun ekstern perusahaan dalam pengambilan keputusan. Akuntansi adalah bahasa bisnis dimana penting bagi seseorang yang melakukan bisnis untuk memahaminya. Akuntansi dibagi menjadi dua kelompok besar, yaitu akuntansi keuangan dan manajemen. Pada umumnya tujuan akuntansi adalah menyajikan informasi ekonomi dari satu kesatuan ekonomi kepada pihakpihak yang berkepentingan.

\section{Akuntansi Biaya}

Menurut Witjaksono (2013 : 3), akuntansi biaya merupakan salah satu dari sekian banyak disiplin ilmu dalam akuntansi. Akuntansi biaya secara sederhana dapat diartikan dari istilahnya sebagai akuntansi yang khususnya digunakan untuk pengukuran dan pelaporan biaya. Akuntansi yang kegiatannya bertujuan menyediakan informasi biaya bagi manajemen disebut akuntansi biaya.

\section{Konsep Biaya}

Menurut Prawironegoro dan Purwanti (2009 : 19), biaya merupakan pengorbanan untuk memperoleh harta, sedangkan beban merupakan pengorbanan untuk memperoleh pendapatan. Ada 5 unsur dalam definisi biaya, yaitu sebagai berikut.

1. Biaya merupakan pengorbanan sumber ekonomi

2. Diukur dalam satuan moneter (rupiah atau dollar)

3. Yang telah terjadi atau secara potensial akan terjadi

4. Pengorbanan tersebut untuk tujuan

5. Suatu aktiva, biaya digunakan ketika menunjuk pada penilaian barang dan jasa yang diinginkan

\section{Biaya Produksi}


Menurut Salman (2013 : 27), perusahaan manfaktur adalah perusahaan yang bergerak dibidang pengolahan bahan baku menjadi barang jadi, atau dengan kata lain untuk memberikan nilai tambah terhadap barang yang diolah sebagai bahan baku. Proses pengolahan bahan baku pada perusahaan manufaktur hingga menjadi barang jadi tidaklah terjadi dengan sendirinya.

\section{Harga Pokok Produksi}

Tujuan dilakukan perhitungan harga pokok produksi menurut Horngren dan Foster (2009: 90) adalah sebagai berikut.

1. Untuk memenuhi keprluan pelaporan eksternal dalam hal penilaian persediaan dan penentuan laba.

2. Untuk pedoman pengambilan keputusan mengenai harga dan strategi produk.

3. Untuk menilai prestasi bawahannya dan bagian organisasi tersebut sebagai investasi ekonomi.

\section{Job Order Costing}

Menurut Simamora (2012 : 61), sistem penentuan pokok pesanan (job order costing) adalah sebuah sistem penentuan biaya pokok produk yang menghimpun dan mengenakan biaya kepada pekerjaan tertentu. Sistem jenis ini diaplikasikan dalam kondisi dimana banyak produk, pekerjaan, atau gugus produksi berbeda yang diproduksi disetiap periodenya. Pekerjaan (job) adalah masing-masing produk atau gugus produk yang informasi biayanya dibutuhkan oleh perusahaan. Dalam sistem penentuan biaya pokok pesanan, biaya produksi dikumpulkan untuk setiap pekerjaan yang terpisah.

\section{Penelitian Terdahulu}

Elfirah (2010) dengan judul Analisis Penentuan Harga Pokok Rumah Perumahan Duta Kenanga Indah Pada PT. Siak Nibung Perkasa di Pekanbaru. Tujuan dari penelitian ini untuk mengetahui apakah penentuan harga pokok rumah yang telah dilakukan PT. Siak Nibung Perkasa telah sesuai dengan prinsip akuntansi yang berlaku umum. Metode yang digunakan adalah metode kuantitatif. Hasil penelitian menujukkan peneliti menghitung harga pokok produksi dengan mengalikan seluruh biaya yaitu biaya tenaga kerja langsung, biaya proyek langsung dan biaya overhead pabrik.

Aripin (2014) dengan judul Analisis Harga Pokok Produksi Tahu-Tempe Pada Home Industry Lela Jaya Manna Bengkulu Selatan. Tujuan dari penelitian ini untuk menganalisis harga pokok produksi tahu-tempe yang dihasilkan home industry Lela Jaya Manna, Bengkulu Selatan. Metode yang digunakan adalah metode kualitatif kuantitatif. Hasil penelitian menunjukkan Perusahaan menghitung Harga Pokok Produksi berdasarkan biaya bahan baku, biaya tenaga kerja dan biaya overhead pabrik dan dihitung untuk mendapatkan harga pokok produksi pada home industry Lela Jaya Manna, Bengkulu Selatan.

\section{Jenis Penelitian}

\section{METODE PENELITIAN}

Penelitian ini merupakan jenis penelitian yang deskriptif kualitatif, yaitu suatu pendekatan investigasi karena peneliti mengumpulkan data dengan cara bertatap muka langsung dan berinteraksi dengan orang-orang di tempat penelitian. Menurut Sedarmayanti dan Hidayat (2011:33) adalah suatu metode dalam pencarian fakta status sekelompok manusia, suatu obyek, suatu kondisi, suatu sistem pemikiran ataupun suatu peristiwa pada masa sekarang dengan interpretasi yang tepat.

\section{Tempat Penelitian}

CV. Trinity merupakan perusahaan yang bertempat di Tikala Ares, Wenang, Manado. Perusahaan ini bergerak dibidang Digital Printing. Alamat lengkap dari CV. Trinity adalah Jl Tikala Ares I/53,Tikala Ares, Wenang, Manado, Indonesia.

\section{Prosedur Penelitian}


Prosedur penelitian yang dilakukan dalam skripsi ini adalah sebagai berikut.

1. Melakukan kunjungan langsung pada objek penelitian.

2. Melakukan wawancara dengan pemilik perusahaan dan bagian staf akuntansi pada CV. Trinity.

3. Mengumpulkan data-data yang diperlukan yang berhubungan dengan penelitian untuk menjadi dasar acuan dalam penelitian.

4. Mengolah data-data yang sesuai dengan dasar teori yang akan digunakan dalam penelitian.

\section{Metode Pengumupulan Data}

1. Survei pendahuluan

Hal ini dilakukan untuk mengetahui kedaaan dari perusahaan secara keseluruhan sehingga dapat menentukan masalah apa yang dihadapi CV. Trinity

2. Survei lapangan

Suvei dilakukan dengan cara berikut ini.

a. Interview, yaitu mengadakan wawancara dalam hal ini tanya jawab dengan pimpinan dan staf yang ditujukan untuk mengadakan penelitian terhadap tata cara pelaporan yang menyangkut masalah tersebut.

b. Documenter, cara pengumpulan data dengan menggunakan arsip dan dokumen-dokumen dari perusahaan yang bersangkutan.

3. Studi kepustakaan

Hal ini dimaksudkan untuk memperoleh landasan teori yang berhubungan dengan permasalahan melalui interview yang ada, yang akan digunakan sebagai pembahasan masalah.

\section{Metode Analisis Data}

Menurut Sugiyono (2003) terdapat beberapa jenis data antara lain sebagai berikut.

1. Data kuantitatif, adalah penelitian dengan memperoleh data yang berbentuk angka atau data kualitatif yang diangkakan

2. Data kualitatif, adalah data yang berbentuk kata, skema, dan gambar.

Jenis data dalam penelitian ini berbentuk kualitatif dan kuantitatif. Yakni disajikan dalam bentuk cerita detail sesuai bahasan dan pandangan responden serta perhitungan menggunakan angka.

Teknik pengumpulan data yang dilakukan melalui studi kepustakaan, studi lapangan, dan media elektronik dengan internet.

\section{Gambaran Umum Objek Penelitian}

\section{HASIL PENELITIAN DAN PEMBAHASAN}

CV. Trinity adalah perusahaan yang didirikan oleh Bapak Andry Yanwar Setio dengan modal sendiri yang bergerak di bidang digital printing. CV Trinity didirikan pada tahun 2008 berlokasi di Tikala Ares I/53, Wenang, Manado. CV Trinity mengembangkan usahanya pada awal tahun 2008 dengan membeli ruko dengan ukuran yang besar serta mesin-mesin digital printing yang memadai. CV. Trinity mempunyai 20 orang karyawan handal yang bekerja secara profesional dalam menangani setiap pesanan dari konsumen sehingga membuat image CV. Trinity sebagai perusahaan dengan produksi berkualitas tinggi. Sampai saat ini CV. Trinity sudah mengalami dua kali pergantian mesin disebabkan oleh banjir yang terjadi pada tahun 2014 di kota Manado. CV. Trinity melayani berbagai jenis pesanan dari seluruh penjuru kabupaten Sulawesi Utara dan semakin berkembang dibawah pimpinan Bapak Andry Yanwar Setio.

\section{Hasil Penelitian}

Biaya produksinya meliputi perhitungan biaya bahan baku, biaya tenaga kerja langsung dan biaya overhead pabrik yang dibebankan pada setiap pesanan. Berdasarkan total biaya produksi maka dapat diketahui harga pokok produk untuk tiap unit produk yang dipesan. Untuk menunjukkan biaya produksi untuk tiap pesanan pada CV. Trinity penulis mengambil contoh perhitungan harga pokok produksi untuk pesanan undangan dan flyer. 


\section{Perhitungan Biaya Bahan Baku}

Perhitungan biaya bahan baku pada CV. Trinity ditentukan dengan cara mengalikan jumlah bahan yang dipakai dengan harga pokok bahan. Adapun perhitungan biaya bahan baku untuk setiap pesanan yang dikerjakan adalah sebagai berikut.

Tabel 1

Biaya Bahan Baku Pesanan Undangan

(1.000 eksemplar)

\begin{tabular}{|l|l|r|r|}
\hline \multicolumn{1}{|c|}{ Jenis } & \multicolumn{1}{|c|}{ Kuantitas } & \multicolumn{1}{c|}{$\begin{array}{c}\text { Biaya yang } \\
\text { dikeluarkan (Rp) }\end{array}$} & $\begin{array}{c}\text { Biaya per eksemplar } \\
\text { (Rp) }\end{array}$ \\
\hline Kertas Art Paper 150 gram & 1000 & 1.000 .000 & 1.000 \\
\hline Tinta Ink Edible & 2 set tinta edible & 800.000 & 300 \\
\hline Plate double folio & 2 lembar & 300.000 & 200 \\
\hline Film 34 x 23 cm & 1 & 200.000 & $\mathbf{2 . 8 0 0}$ \\
\hline Total & & $\mathbf{2 . 8 0 0 . 0 0 0}$ & 300 \\
\hline
\end{tabular}

Sumber: Data CV. Trinity

Tabel 1 menunjukkan bahwa jumlah biaya bahan baku yang diperlukan untuk memproduksi pesanan undangan sebanyak 1.000 ekslempar adalah $\mathrm{Rp} 2.800 .000$ yang artinya setiap undangan memerlukan bahan baku sebesar Rp 2.800.000.

Sementara itu, jumlah bahan baku yang di pergunakan untuk mengerjakan pesanan flyer adalah sebagai berikut.

Tabel 2

Biaya Bahan Baku Pesanan Flyer

(2.000 lembar)

\begin{tabular}{|l|l|r|r|}
\hline \multicolumn{1}{|c|}{ Jenis } & \multicolumn{1}{|c|}{ Kuantitas } & $\begin{array}{c}\text { Biaya yang } \\
\text { dikeluarkan (Rp) }\end{array}$ & Biaya per lembar (Rp) \\
\hline Kertas Art Paper 85 Gram & 1 set tinta edible & 400.000 & 200 \\
\hline Tinta ink Edible & 2.000 & 1.200 .000 & 600 \\
\hline Total & & $\mathbf{1 . 6 0 0 . 0 0 0}$ & $\mathbf{8 0 0}$ \\
\hline
\end{tabular}

Sumber: Data CV. Trinity

Tabel 2 menunjukkan bahwa jumlah biaya bahan baku yang diperlukan untuk memproduksi pesanan flyer sejumlah 2000 lembar adalah Rp. 1.600.000. Yang artinya setiap lembar flyer memerlukan biaya bahan baku sebesar Rp. 800 .

\section{Perhitungan Biaya Tenaga Kerja Langsung}

CV. Trinity menentukan biaya tenaga kerja langsung berdasarkan biaya sesungguhnya yang dikeluarkan dikalikan dengan kuantitas jam kerja maupun jumlah tenaga yang digunakan dalam melakukan kegiatan produksinya yang dilakukan oleh karyawan bagian produksi sehingga terdapat biaya sesungguhnya yang terjadi. Besarnya biaya tenaga kerja langsung untuk masing-masing jenis pesanan adalah sebagai berikut. 
Tabel 3

Biaya Tenaga Kerja Langsung Pesanan Undangan (1.000 eksemplar)

\begin{tabular}{|c|c|c|c|c|c|}
\hline Bagian & $\begin{array}{c}\text { Karyawan } \\
\text { (Orang) }\end{array}$ & $\begin{array}{l}\text { Upah per } \\
\text { hari (Rp) }\end{array}$ & Hari Kerja & $\begin{array}{c}\text { Total } \\
\text { BTK }(\mathbf{R p}) \\
\end{array}$ & $\begin{array}{c}\text { Biaya per eksemplar } \\
(\mathrm{Rp})\end{array}$ \\
\hline Desain & 1 & 35.000 & 2 & 70.000 & 70 \\
\hline Cetak & 1 & 45.000 & 4 & 180.000 & 180 \\
\hline Finishing & 1 & 15.000 & 3 & 45.000 & 45 \\
\hline Total & & & & 295.000 & 295 \\
\hline
\end{tabular}

Sumber: Data CV. Trinity

Tabel 3 di atas menunjukkan bahwa jumlah biaya tenaga kerja langsung yang diperlukan untuk memproduksi pesanan undangan sejumlah 1.000 eksemplar adalah Rp. 295.000 yang artinya setiap eksemplar pesanan undangan biaya tenaga kerja langsung sebesar Rp 295. Sementara itu, jumlah biaya tenaga kerja langsung yang dipergunakan untuk mengerjakan pesanan flyer adalah sebagai berikut

Tabel 4

Biaya Tenaga Kerja Langsung Pesanan Flyer

(2.000 lembar)

\begin{tabular}{|l|c|c|c|r|r|}
\hline \multicolumn{1}{|c|}{ Bagian } & $\begin{array}{c}\text { Karyawan } \\
\text { (Orang) }\end{array}$ & $\begin{array}{c}\text { Upah per hari } \\
(\mathbf{R p})\end{array}$ & Hari kerja & $\begin{array}{c}\text { Total } \\
\text { BTK (Rp) }\end{array}$ & $\begin{array}{c}\text { Biaya per } \\
\text { lembar (Rp) }\end{array}$ \\
\hline Desain & 1 & 30.000 & 1 & 30.000 & 15 \\
\hline Cetak & 1 & 40.000 & 1 & 40.000 & 20 \\
\hline Finishing & 1 & 15.000 & 2 & 30.000 & 15 \\
\hline Total & & & & $\mathbf{1 0 0 . 0 0 0}$ & $\mathbf{5 0}$ \\
\hline
\end{tabular}

Sumber: Data CV. Trinity

Tabel 4 menunjukkan bahwa jumlah biaya tenaga kerja langsung yang di perlukan untuk memproduksi pesanan flyer sejumlah 2.000 lembar adalah Rp. 100.000 yang artinya setiap lembar memerlukan biaya sebesar Rp. 50.

\section{Perhitungan Biaya Overhead Pabrik}

Biaya overhead pabrik merupakan semua biaya produksi selain biaya bahan baku dan tenaga kerja langsung yang dikeluarkan selama proses produksi. Besarnya BOP yang sesungguhnya untuk undangan dapat dilhat dari tabel 5 berikut ini.

Tabel 5

Biaya Overhead Pabrik Pesanan Undangan

(1.000 eksemplar)

\begin{tabular}{|l|l|r|r|}
\hline \multicolumn{1}{|c|}{ Jenis-jenis biaya } & \multicolumn{1}{|c|}{ Kuantitas } & Jumlah biaya (Rp) & Biaya per eksemplar (Rp) \\
\hline Plastik cover & 1.000 lembar & 90.000 & 90 \\
\hline Label & 25 lembar & 50.000 & 50 \\
\hline Kardus & 2 buah & 10.000 & 10 \\
\hline Pita & 4 rol & 40.000 & 40 \\
\hline Total & & $\mathbf{1 9 0 . 0 0 0}$ & $\mathbf{1 9 0}$ \\
\hline
\end{tabular}

Sumber: Data CV. Trinity

Tabel 5 menunjukkan bahwa total BOP yang sesungguhnya untuk pesanan undangan adalah sebesar Rp 190.000 dengan jumlah pesanan 1.000 eksemplar, maka diketahui bahwa BOP per unitnya Rp 190.

Sementara itu, besarnya BOP yang sesungguhnya untuk pesanan flyer dapat dilihat pada Tabel 6 . 
Tabel 6

Biaya Overhead Pabrik Pesanan Flyer

(2.000 lembar)

\begin{tabular}{|l|l|r|r|}
\hline \multicolumn{1}{|c|}{ Jenis-jenis biaya } & \multicolumn{1}{c|}{ Kuantitas } & Jumlah Biaya (Rp) & Biaya per lembar (Rp) \\
\hline Kardus & 2 buah & 10.000 & 5 \\
\hline Tali & 1 rol & 6.000 & 3 \\
\hline Total & & $\mathbf{1 6 . 0 0 0}$ & $\mathbf{8}$ \\
\hline
\end{tabular}

Sumber: Data CV. Trinity

Tabel 6 menunjukkan bahwa total BOP yang sesungguhnya untuk pesanan flyer adalah Rp. 16.000 dengan jumlah pesanan 2.000 lembar, maka diketahui bahwa BOP per unitnya Rp. 8 .

\section{Perhitungan Harga Pokok Produksi oleh CV. Trinity}

Setelah semua unsur biaya produksi baik bahan baku, biaya tenaga kerja langsung, dan BOP dapat dikumpulkan, dihitung, dan dibebankan, maka harga pokok produksi untuk masing-masing pesanan dapat ditentukan. Berikut ini perihitungan harga pokok produksi pada masing-masing pesanan.

Tabel 4.7 menunjukkan bahwa total biaya produksi dibebankan untuk pesanan undangan adalah Rp. 3.285.000 sehingga harga pokok produksi dikeluarkan per eksemplar adalah Rp. 3.285 dan untuk pesanan flyer besarnya biaya produksi sebesar Rp. 1.716 .000 sehingga harga pokok produksi perbuku adalah sebesar Rp 858.

Tabel 7

Perhitungan Harga Pokok Produksi untuk Undangan dan Flyer

\begin{tabular}{|c|c|c|c|}
\hline Biaya Produksi & $\begin{array}{c}\text { Pesanan } \\
\text { Undangan } \\
\mathbf{1 . 0 0 0} \text { eks (Rp) }\end{array}$ & $\begin{array}{c}\text { Pesanan Flyer } \\
\text { 2.000 lembar (Rp) }\end{array}$ & Total (Rp.) \\
\hline Biaya bahan baku & 2.800 .000 & 1.600 .000 & 4.400 .000 \\
\hline Biaya tenaga kerja langsung & 295.000 & 100.000 & 395.000 \\
\hline BOP & 190.000 & 16.000 & 206.000 \\
\hline Harga pokok roduksi & 3.285 .000 & 1.716 .000 & \\
\hline
\end{tabular}

Sumber: Data CV. Trinity

Tabel diatas menunjukkan bahwa harga pokok produksi unuk pesanan undangan sebesar Rp. 3.285.000 dengan biaya per eksemplar sebesar Rp. 3.285 dan harga pokok produksi untuk pesanan flyer sebesar Rp. 1.716.000 dengan biaya per lembar sebesar Rp. 858.

\section{Pembahasan}

Setelah biaya bahan baku, biaya tenaga kerja langsung dan jumlah BOP dihitung dapat dilihat bahwa biaya overhead pabrik yang ditetapkan CV. Trinity kurang tepat. Pada Tabel 4.8 penulis menambahkan biaya listrik yang seharusnya ada pada biaya overhead pabrik pada pesanan undangan dan flyer.

Tabel 8

Biaya Overhead Pabrik Pesanan Undangan

(1.000 eksemplar)

\begin{tabular}{|l|l|r|r|}
\hline \multicolumn{1}{|c|}{ Jenis-jenis biaya } & \multicolumn{1}{|c|}{ Kuantitas } & Jumlah biaya (Rp) & Biaya per eksemplar (Rp) \\
\hline Plastik cover & 1.000 lembar & 90.000 & 90 \\
\hline Label & 25 lembar & 50.000 & 50 \\
\hline Kardus & 2 buah & 10.000 & 10 \\
\hline
\end{tabular}




\begin{tabular}{|l|l|r|r|}
\hline Pita & 4 rol & 40.000 & 40 \\
\hline Listrik & 3 mcb meter & 300.0000 & 300 \\
\hline Total & $\mathbf{4 9 0 . 0 0 0}$ & $\mathbf{4 9 0}$ \\
\hline
\end{tabular}

Tabel 8 menunjukkan bahwa total BOP yang sesungguhnya ditambah biaya listrik untuk pesanan undangan adalah sebesar Rp 490.000 dengan jumlah pesanan 1.000 eksemplar, maka diketahui bahwa BOP per unitnya Rp 490.

Perhitungan biaya listrik dari BOP untuk pembuatan undangan diambil dari jumlah biaya listrik keseluruhan per bulan CV. Trinity sebesar Rp. 3.000 .000 untuk semua produk. Biaya pesanan undangan diambil $10 \%$ dari Rp. 3.000 .000 yaitu Rp. 300.000 dibagi 1000 eksemplar menjadi Rp. 300.

Sementara itu, besarnya BOP yang sesungguhnya untuk pesanan Flyer dapat dilihat pada tabel 9 berikut ini.

Tabel 9

Biaya Overhead Pabrik Pesanan Flyer

(2.000 lembar)

\begin{tabular}{|l|l|r|r|}
\hline \multicolumn{1}{|c|}{ Kenis-jenis biaya } & \multicolumn{1}{c|}{ Kuantitas } & Jumlah biaya (Rp) & Biaya per lembar (Rp) \\
\hline Kardus & 2 buah & 10.000 & 5 \\
\hline Tali & 1 rol & 6.000 & 3 \\
\hline Listrik & 3 mcb meter & 300.000 & 150 \\
\hline Total & & $\mathbf{3 1 6 . 0 0 0}$ & $\mathbf{1 5 8}$ \\
\hline
\end{tabular}

Sumber: Hasil Olahan

Tabel 9 menunjukkan bahwa total BOP yang sesungguhnya untuk pesanan flyer adalah Rp. 16.000 dengan jumlah pesanan 2.000 lembar, maka diketahui bahwa BOP per unitnya Rp. 8 .

Perhitungan biaya listrik dari BOP untuk pembuatan flyer diambil dari jumlah biaya listrik keseluruhan per bulan CV. Trinity sebesar Rp. 3.000.000 untuk semua produk. Biaya pesanan undangan diambil 10\% dari Rp. 3.000 .000 yaitu Rp. 300.000 dibagi 1000 ekslempar menjadi Rp. 300.

\section{Perbandingan Perhitungan Biaya Bahan Baku, Biaya Tenaga Kerja Langsung dan Biaya Pabrik Overhead}

Perhitungan biaya bahan baku, biaya tenaga kerla langsung dan biaya overhead pabrik pada $\mathrm{CV}$. Trinity dan oleh penulis ditentukan dengan cara menjumlahkan seluruh total jenis biaya dalam satu tabel untuk menghasilkan keseluruhan biaya tersebut. Berikut ini adalah tabel perbandingan perhitungan undangan dan flyer antara CV. Trinity dan teori akuntansi menejemen.

Tabel 10

Perbandingan Perhitungan Biaya Bahan Baku, Biaya Tenaga Kerja Langsung, Biaya Overhead Pabrik Undangan Menurut CV. Trinity dan Pembahasan

(1.000 eksemplar)

\begin{tabular}{|c|r|r|}
\hline \multirow{2}{*}{ Jenis-jenis Biaya } & \multicolumn{2}{|c|}{ Job Order Costing } \\
\cline { 2 - 3 } & CV. Trinity & \multicolumn{2}{c|}{ Pembahasan } \\
\hline Bahan baku & 2.800 .000 & 2.800 .000 \\
\hline Tenaga kerja langsung & 295.000 & 295.000 \\
\hline Overhead pabrik & 190.000 & 490.000 \\
\hline Total & $\mathbf{3 . 2 8 5 . 0 0 0}$ & $\mathbf{3 . 5 8 5 . 0 0 0}$ \\
\hline
\end{tabular}

Sumber : Hasil Olahan

Pada Tabel 10 dapat dilihat kesamaan perhitungan biaya bahan baku dengan biaya tenaga kerja langsung dari CV. Trinity dan menurut pembahasan. Sedangkan biaya overhead pabrik undangan memiliki perbedaan perhitungan yang terdapat pada pembahasan senilai Rp. 300.000. 
Penulis memasukkan biaya listrik dalam perhitungan biaya overhead pabrik agar dapat dilihat ketepatan dalam perhitungan biaya overhead pabrik. Biaya listrik penulis masukkan ke dalam biaya overhead pabrik dikarenakan biaya listrik termasuk dalam biaya yang berhubungan langsung dengan produk yang dibuat.

Tabel 11

Perbandingan Perhitungan Biaya Bahan Baku, Biaya Tenaga Kerja Langsung, Biaya Overhead Pabrik Flyer Menurut CV. Trinity dan Pembahasan (2.000 lembar)

\begin{tabular}{|c|c|c|}
\hline \multirow{2}{*}{ Jenis-jenis Biaya } & \multicolumn{2}{|c|}{ Job Order Costing } \\
\cline { 2 - 3 } & CV. Trinity & Pembahasan \\
\hline Bahan baku & 1.600 .000 & 1.600 .000 \\
\hline Tenaga kerja langsung & 100.000 & 100.000 \\
\hline Overhead pabrik & 16.000 & 316.000 \\
\hline Total & $\mathbf{1 . 7 1 6 . 0 0 0}$ & $\mathbf{2 . 0 1 6 . 0 0 0}$ \\
\hline
\end{tabular}

Sumber : Hasil Olahan

Pada Tabel 11 dapat dilihat kesamaan perhitungan biaya bahan baku dengan biaya tenaga kerja langsung flyer dari CV. Trinity dan menurut pembahasan. Sedangkan biaya overhead pabrik flyer memiliki perbedaan perhitungan yang terdapat pada pembahasan senilai Rp. 300.000. Penulis memasukkan biaya listrik dalam perhitungan biaya overhead pabrik agar dapat dilihat ketepatan dalam perhitungan biaya overhead pabrik. Biaya listrik penulis masukkan ke dalam biaya overhead pabrik dikarenakan biaya listrik termasuk dalam biaya yang berhubungan langsung dengan produk yang dibuat.

\section{PENUTUP}

\section{Kesimpulan}

Dari hasil penelitian dan pembahasan di atas penulis mengambil kesimpulan bahwa CV. Trinity telah menggunakan metode job order costing tetapi cara pembebanan BOP yang dilakukan $\mathrm{CV}$. Trinity kurang tepat karena percetakan CV. Trinity hanya membebankan unsur BOP berupa bahan penolong saja. Jumlah BOP yang dibebankan untuk pesanan undangan sebesar Rp. 190.000 jumlah yang dibebankan ini terlalu kecil karena unsur BOP yang lain seperti biaya listrik tidak ikut dibebankan. Akibat dari hal ini adalah harga pokok produksi terlalu kecil, sehingga harga jual yang ditetapkan juga terlalu kecil dan CV. Trinity tidak mampu mencapai tingkat keuntungan yang diharapkan atas produksi pesanan undangan dan flyer. Seharusnya CV. Trinity menggunakan tarif BOP ditentukan di muka dalam pembebanan BOP untuk masing-masing pesanan. Untuk dapat menentukan tarif dan jumlah BOP yang dibebankan CV. Trinity dapat menggunakan dasar biaya bahan baku, mengingat bahwa unsur BOP yang paling dominan adalah proses produksi CV. Trinity adalah bahan penolong dan perubahan bahan penolong dipengaruhi oleh pemakaian bahan baku. CV. Trinity belum menyelenggarakan Kartu Harga Pokok Produksi pesanan untuk tiap-tiap pesanan yang diterima dan diproduksi. Kartu Harga Pokok Pesanan ini penting bagi CV. Trinity untuk mendokumentasikan infomasi biaya produksi dan Harga Pokok Produksi masing-masing pesanan sehingga membantu CV. Trinity dalam pengambilan keputusan harga jual dan membantu dalam mempermudah pencarian kembali informasi biaya produksi dikemudian hari ketika diterima pesanan yang sama.

\section{Saran}

Saran penulis kepada perusahaan tentang penerapan metode job order costing dalam menentukan harga pokok produksi dari penelitian diatas seharusnya perusahaan tidak membebankan BOP yang berupa bahan penolong saja, karena masih terdapat unsur-unsur BOP lain seperti biaya listrik yang berhubungan langsung dengan produk harus dibebankan pada produk yang di produksi. Hal ini perlu dilakukan agar jumlah BOP yang dibebankan tidak terlalu kecil dan harga jual yang ditetapkan tidak terlalu kecil. CV. Trinity juga seharusnya menggunakan kartu harga pokok pesanan 
untuk setiap pesanan yang diterima dan diproduksi guna mendokumentasikan dan merinci informasi biaya produksi sehingga dapat membantu managemen CV. Trinity dalam pengambilan keputusan harga jual dan mempermudah CV. Trinity dalam menemukan kembali informasi biaya produksi ketika terdapat pesanan yang mempunyai karakteristik sama dikemudian hari.

\section{DAFTAR PUSTAKA}

Ahmad, Firdaus, Abdullah, Wasila, 2012. Akuntansi Biaya. Edisi Ketiga. Salemba Empat. Jakarta. Fauziah Elfira, 2010, Analisis Penentuan harga pokok Perumahan Duta kenangan indah pada PT. Siak Nibung Perkasa Pekan Baru. http://digilib.uir.ac.id/dmdocuments/s1\%20akt,fauziah\%20elfira.pdf. Diakses Januari $15,2016$.

Horngren, Datar, Foster, George, 2009. Akuntansi Biaya dengan Penekanan Manajerial. Jilid 1. Edisi keduabelas. Erlangga. Jakarta.

Prawinegoro, Purwanti. 2009. Akuntansi manajemen. Edisi II . PT.Indeks.

Salman, Kautsar. 2013. Akuntansi Biaya: Pendekatan Product Costing. Cetakan Pertama. Indeks. Kembangan Utara-Jakarta Barat 11610.

Sedarmayanti dan Syarifudin Hidayat. 2011. Metodologi Penelitian. Penerbit : CV. Mandar Maju.

Simamora, Henry. 2012. Akuntansi Manajemen. Edisi III. Star Gate Publisher. Duri. Riau.

Smith, Skousen. 1987. Akuntansi Intermediate. Edisi Kesembilan. Penerbit: Salemba Empat.

Witjaksono, Armanto. 2013. Akuntansi Biaya. Graha Ilmu : Yogyakarta.

Zainal Aripin, 2014, Analisis harga pokok produksi tahu-tempe pada home industry Lela Jaya Manna, Bengkulu Selatan. https://digilib.uns.ac.id/dokumen/download/6799/MTc4ODU=/analisisharga-pokok-produksi-tahu-tempe-pada-home-industri-lela-jaya-manna.pdf. Diakses Januari $8,2016$. 